$0.00^{\prime \prime}$ in N.P.D. The moon was observed on 146 days during the year, and observations of Mars and of Halley's comet, in and out of the meridian, were also secured.

Double stars and planetary diameters were measured with the 28 -inch refractor, 150 of the pairs having separations less than $0.5^{\prime \prime}$ and 296 pairs less than $\mathrm{I} \cdot \mathrm{0}^{\prime \prime}$.

With the 26 -inch refractor 146 planetary photographs were secured, including sixty-two of Mars, taken between July 23 , 1909, and May 14, for an investigation of its orbit.

Planets, satellites, and comets rgoga, $b, c$ (Halley's), and $e$ were also photographed with the 30 -inch reflector; among these were twelve photographs of Saturn and Phoebe, thirteen of Jupiter and J.viii., and forty-four of Halley's comet. The first photograph of J.viii. during this opposition was secured on January 19, and the observed correction to the position given by the Cowell-CrommelinDavidson orbit nas only $7^{\prime \prime}$; this satellite has now performed one complete revolution since its discovery. A slight elongation of the images taken with the 30 -inch reflector was attributed to a small shift of the mirror cell, and has been completely eliminated by rounding the ends of the supporting screws and making hollows to receive them in the bed on which the cell rests. A 6-inch lens, kindly lent by $\mathrm{Mr}$. Franklin Adams for photographing the extensions of the tail of Halley's comet, and a prismatic camera for photographins the spectrum, were attached to the 3o-inch reflector, but the bright twilight and low altitude of the comet prevented the latter observations.

The work on the Greenwich astrographic zones being complete, the 13-inch astrographic refractor was employed until April for cometary and various other photographic observations. Since then it has been used for photographing the astrographic zones $+25^{\circ}$ to $+31^{\circ}$, originally allotted to the Oxford University Observatory. The stars on these chart plates are also to be counted at Greenwich, as are also those on the catalogue plates, which are being re-taken for the purpose. For photographing Halley's comet a new Ross lens of 4 inches aperture and 16 inches focal length has been attached to the ro-inch finder of the astrographic instrument.

Of the 3.07 days' difference between the perihelion passage of Halley's comet and the date predicted by Drs. Cowell and Crommelin, one day has beti accounted for in a rediscussion of the perturbations during $1828-42$, but the further discordance of two days is as yet unaccounted for by any attraction of known matter in the solar system. The observations show that none of the other elements was so much as $\mathrm{x}^{\prime}$ in error.

During the period dealt with by the report the sun was photographed at Greenwich on I94 days, and the Royal Observatory contributed I7I days towards the record for I909, which is now complete, with the assistance of the Dehra Dûn and Kodaikanal Observatories, except for two days. In this work the Cape Observatory now replaces the Royai Alfred Observatory, Mauritius, and the hope is expressed that the yearly record may be made up almost entirely from the plates taken at the two Royal Observatories, Greenwich and the Cape; during March their record was complete except for one day.

The magnetic observations were carried on as usual, but the registration of earth currents was discontinued at the end of 1909 because new wiring was found to be necessary, and was considered unjustified owing to the disturbances produced by the electric trams, \&c.

For 1909 the principal magnetic results were :-

$$
\begin{array}{rlll}
\text { Mean declination } \ldots & \ldots & \ldots & 35^{\circ} 47^{\circ} 6^{\prime} \mathrm{W} . \\
4^{\circ} \text { OI } 79 \text { in British units } \\
, \quad \text { horizontal force } & \ldots & \ldots & 8526, " \text { metric } \\
\text {, } & \text { dip (3-inch needles) } & \ldots & 66^{\circ} 53^{\prime} 57^{\prime \prime}
\end{array}
$$

Two days of "greater" and six days of "lesser" disturbance were registered by the magnets.

The reductions of the meteorological observations are complete to date, and show that the mean temperature of 1909 was $48.6^{\circ}, 1^{\circ}$ below the 65 -year average $184 \mathrm{I}-1905$. The rainfall for the year ended April 30 was 27.72 inches, 3.6 above the average, and the number of "rainy days" was 192, the highest for many years.

The performance of the chronometers tested was satisfactory, and in future non-magnetic watches are to be received and submitted to the same tests as the chrono- meter watches. A new trial of box chronometers commenced on June 18 , and the next trial of pocket chronometers and chronometer watches will commence on July 30. The time-signal service was also satisfactory, and the performance of the Westminster clock ("Big Ben ") left little to be desired. On 4I per cent. of the days its error was less than 0.5s., on 77 per cent. less than r.os., and on 98 per cent. less than 2.0s.; it never exceeded three seconds.

The vacancy on the personnel caused by the resignation of Dr. Cowell has not yet been filled, and, in closing the report, Sir William Christie tenders his hearty thanks to tine staff for their loyal cooperation in the prosecution and extension of the observatory's work during his tenure of the office of Astronomer Royal. Although the work has been enormously extended during the past thirty years, the financial provision for it has been increased by only $2200 l$. per annum.

\section{AGRICULTURAL RESEARCH.}

THE need for widely extended facilities for agricultural research is being more and more recognised both by men of science and by our administrative authorities. At the last meeting of the executive committee of the British Science Guild a memorial to the Prime Minister on the subject of research in agriculture was approved. The President of the Board of Agriculture and Fisheries has now appointed a committee to advise the Board as to horv agricultural research may be best encouraged and improved. Lastly, a society has been incorporated to secure the development and extension of the investigations inaugurated and endowed by the late Sir John Lawes. These are all excellent indications that a determined and united effort is to be made to place agricultural practice upon a scientific basis, and to secure for the British farmer all the help science is able to provide.

The committee appointed by Earl Carrington to advise the Board of Agriculture on all scientific questions bearing directly on the improvement of agriculture will deal especially with the methods to be adopted $(a)$ for promoting agricultural research in universities and other scientific schools; $(b)$ for aiding scientific workers engaged in the study of agricultural problems; and $(c)$ for ensuring that new scientific discoveries are utilised for the benefit of agriculturists.

The committee will consist of the Duke of Devonshire Lord Reay, Sir Edward Thorpe, C.B., F.R.S., Mr. David Davies, M.P., Dr. J. J. Dobbie, F.R.S. (principal of the Government Laboratories), Prof. J. B. Farmer, F.R.S., Dr. S. F. Harmer, F.R.S. (keeper of zoology at the Natural History Museum), Dr. R. Stewart MacDougall (technicas adviser in zoology to the Board of Agriculture and Fisheries), Mr. T. H. Middleton (one of the assistantsecretaries to the Board of Agriculture and Fisheries), Mr. Spencer P. Pickering, F.R.S., Lieut.-Colonel David Prain, C.I.E., F.R.S. (director of the Royal Botanic Gardens, Kew), Mr. H. S. Staveley-Hill, M.P., Mr. Stewart Stockman (chief veterinary officer of the Board of Agriculture and Fisheries), Dr. J. J. H. Teall, F.R.S. (director of the Geological Survev and Museum), and Dr. David Wilson. Mr. Middleton will act as chairman of the committee, and one of the officers of the Intelligence Division of the Board will act as secretary.

A meeting of the Society for Extending the Rothamsted Experiments was held at Rothamsted on June 16 under the presidency of the Duke of Devonshire. The society has been incorporated with the object of obtaining additional funds for the development of the agricultural investigations which have been carried on so long under the late Sir John Lawes and the Lawes Agricultural Trust which he afterwards founded. The immediate object of the society is to obtain a sum of $5000 \mathrm{l}$. in order to secure about 200 acres of land adjoining the present experimental fields, and erect thereon the buildings required for feeding experiments with the crops under investigation.

An appeal for subscriptions towards thus securing a small self-contained farm for the Rothamsted Experimental Station is now being circulated, and at this meeting of the society a first list of donations was reported from the Duke of Devonshire, Lord Iveagh, Sir J. T. Brunner, Colonel E. H. Carlile, M.P., Mr. J. F. Mason, M.P., and Mr. J. Martin White, amounting to $145 \mathrm{ol}$. 